\title{
Disparities in Pain Management in the Emergency Department: An Integrative Review
}

\author{
Melanie Johnson, Katrina Richardson, Suha Al-Oballi Kridli \\ Oakland University, Rochester, USA \\ Email: kridli@oakland.edu
}

Received 22 May 2014; revised 26 June 2014; accepted 18 July 2014

Copyright (C) 2014 by authors and Scientific Research Publishing Inc.

This work is licensed under the Creative Commons Attribution International License (CC BY). http://creativecommons.org/licenses/by/4.0/

c) (i) Open Access

\section{Abstract}

Purpose: The purpose of this integrative review is to investigate the degree of variability in the prescribing approaches to acute pain management in the emergency department (ED) setting. Variations in analgesic prescribing among ethnic and racial minorities as they compare to nonminority patients with similar complaints of pain will be examined. Data Sources: A comprehensive review of the literature was conducted using MEDLINE, PubMed, and CINAHL databases. Inclusion criteria of the studies were: US studies; published between 2002 and 2012; English language; with at least one aim or analysis comparing prescription of analgesia between a racial or ethnic minority and non-minority group in the ED. Key words used to obtain relevant articles included pain management; analgesia prescription; minority; race; ethnicity; emergency department; disparities. Conclusion: A research summary concluded that racial and ethnic disparities in pain management continue to exist in the ED setting. When compared to Caucasian patients, African American and non-white ethnicities were less likely to receive analgesia. Language barriers, experience of providers, and trust were among the contributors to pain management disparities. Implications for Practice: The role of the nurse is to incorporate cultural competence in assessing and achieving equitable pain management across all racial/ethnic groups.

\section{Keywords}

Pain, Emergency, Analgesia, Integrative Review

\section{Introduction}

Pain is defined as, "a basic bodily sensation that is induced by a noxious stimulus, is received by naked nerve 
endings, is characterized by physical discomfort (as pricking, throbbing, or aching), and typically leads to evasive action [1]. Acute pain is frequently short-lived and self-limiting, but "can become persistent and intractable if the underlying disease process or injury is chronic or incurable, or if the activation of pain is unavoidable, as in the pain caused by movement or weight bearing in injuries of the spine or in disease such as arthritis” [2]. Patients usually present to the Emergency Department (ED) when there is a lack of access to other providers, or when symptoms, such as pain, are severe [3]. There were 136 million visits to EDs in the United States between December 2008 and December 2009 with 35.3\% resulting in analgesic prescribing [4].

In 1986, the Emergency Medical Treatment and Active Labor Act (EMTALA) was passed to ensure access to emergency medical care irrespective of the patients ability to pay [5] The ED is often the point of entry for accessing the healthcare system for the medically underserved and serves as a safety net for those that are uninsured or have no regular access to care [6] [7]. In 2011, there were 46.3 million (15.1\%) uninsured persons in the United States and 23\% under the age of 65 covered by public health insurance [8]. Hispanic and non-Hispanic Blacks have higher uninsured rates that Asian/Pacific Islanders, and non-Hispanic Whites [9]. The National Health Interview Survey (NHIS) conducted in 2011 found that uninsured adults and those with public health plans were more likely than those with private health insurance to visit the ED [3]. In addition, statistics show that ethnic minority populations utilize the ED at a higher rate than the general population. Around 85 per 100 Blacks and 39.8 per 100 non-White Hispanics utilized the ED in December 2008-December 2009, compared to 41.3 per 100 non-Hispanic Whites and 24.2 per 100 "other" groups, characterized as Asian/Pacific Islanders, American Indian, and Alaskan Natives [4].

Disparities in pain management have been increasingly gaining more attention over the past decade. On January 1, 2001, pain was declared the fifth vital sign by the Joint Commission on the Accreditation of Health Organizations (JCAHO) and mandated to be assessed as such in certain health care settings [10]. A large body of research indicates that minority patients, particularly underserved patients of lower socioeconomic status, tend to be most at risk for untimely and inadequate pain management, or oligoanalgesia [10]-[13]. This is especially evident in the ED setting [14] [15]. Although ED physicians should be well-versed in pain management, they have long been accused of poor assessment and poor prescribing practices of minority patients [16]. Reasons for oligoanalgesia among these groups have been cited as lack of trust; perceived exaggeration of pain, or drug seeking; lack of training; fear of side effects; prejudice; and racial stereotyping [17]-[20]. If pain is left untreated, it can impair function and diminish the quality of life [16]. Patients are at the mercy of the provider to manage every aspect of their care, including pain. The inadequacies and inconsistencies in pain management among the minority ethnic groups deserve attention and investigation in an effort to formulate a more equitable plan of care.

\section{Purpose}

The purpose of this integrative review is to investigate the degree of variability in the prescribing approaches to acute pain management in the Emergency Department setting. This review will examine the variations in analgesic prescribing practices among ethnic and racial minorities as they compare to non-minority patients with similar complaints of pain.

\section{Significance}

Pain possesses physiological, psychological, economic, and social consequences, if inadequately addressed. Unrelieved, acute pain, elicits pathophysiologic neural alterations that may result in chronic pain syndromes, thus, placing the patient at risk for negative physical, psychological, and social consequences [21] [22]. Unrelieved pain affects multiple body system functions, including mobility, sleep, appetite, and immunity. The inadequacy of pain management also places the patient at risk for unconventional pain relief options such as utilizing the prescription drugs of others, substance abuse, over use and dependence upon caregivers, and overuse and inappropriate use of the healthcare system [21]-[23].

Pain management is an evolving research topic that lacks guidelines and gold standards of care. Brennan, Carr, \& Cousins (2007), stated that "because pain management is the subject of many initiatives within the disciplines of medicine, ethics and law, we are at an 'inflection point' in which unreasonable failure to treat pain is viewed worldwide as poor medicine, unethical practice, and an abrogation of a fundamental human right” [24]. 


\section{Conceptual Framework}

The systematic approach developed by Cooper (1984) was the guiding framework for this integrative review. Cooper identifies the process of conducting an integrative review as encompassing the following five stages: a) problem formulation, b) data collection or literature search, c) data evaluation, d) data analysis and interpretation, and e) public presentation of results [25]. Any literature review requires subjective decisions that can lead to procedural variations and affect the outcomes of research studies or research reviews. The validity of the conclusions of research or research reviews depends on the decisions made at each stage [26]. Methodological choices at each review stage may engender threats to the validity of the reviews conclusions.

The integrative literature review provides several contributions to the scholarly reviewer, which include evaluating the strength of scientific evidence, identifying gaps in past and current research, identifying the need for future research, bridging between related area of inquiry, identifying central issues in an area, and identifying whether theoretical or conceptual frameworks are utilized [27]. According to Whittemore and Knafl (2005), "A well done integrative review present the state of the science, contributes to theory development, and has direct applicability to practice and policy” [28]. The review builds from the underlying premise that locating and integrating separate research projects involves inferences as central to the validity of knowledge as the inferences involved in primary data interpretation [26].

\subsection{Background}

Pain is the reason that the majority of patients present to the emergency department (ED). Analgesic management should begin as soon as possible when pain is indicated. Patients with pain may access care through the ED due to being uninsured or underinsured. Reports of undertreatment, or oligoanalgesia, among racial \& ethnic minorities have been reported. For example, in a study conducted in the ED by Tamayo-Sarver et al. (2003) the researchers found that Blacks and Latinos were 28\% less likely than Whites to receive opioid analgesics [19]. Pletcher et al. (2008) found, racial and ethnic minority groups appear to be at particularly high risk of receiving inadequate treatment for pain in the ED. The study concluded that Hispanics with long-bone fractures presenting to an ED were twice as likely to receive no opioid analgesic compared with non-Hispanic whites [29]. Additionally, Todd et al. (1993) reported that Hispanics with isolated long-bone fractures were twice as likely as nonHispanic Whites to receive no pain medication during their ED stay [14]. Much of the research indicates that minority patients are at risk for poor pain management and undertreatment [11] [12]. Finally, in a study by Platts-Mills et al. (2012), white patients were more likely than non-whites to receive an opioid prescription for a pain-related visit [30]. The physicians' underestimations of pain severity in minority patients contribute to disparities and the complexity of pain management in this population [13].

\subsection{Methods}

The design selected for this research is an integrative review. According to Cooper (1982), this five stage research process summarizes and synthesizes information from various sources, highlighting the most relevant issues [26]. The inclusion of diverse methodologies (i.e. experimental and non-experimental research) to provide a full understanding of a phenomenon makes the integrative review one of the comprehensive types of research reviews [28].

The target population consisted of research conducted regarding disparities in pain management among minority populations. While library resources were sought, the majority of the studies were obtained through online computer sources. The criteria for inclusion of the studies was: a) publication between 2002 and 2012; b) publication in English language; c) studies conducted in the United States; and d) at least one aim or analysis comparing prescription of analgesia for pain between a racial or ethnic minority and non-minority group in the ED.

The studies for this review were obtained through exhaustive online computer searches utilizing the following databases; MEDLINE, PubMed, and CINAHL. The following key words were used: pain management, racial disparities, ethnic disparities, minorities, provider decision making, chronic pain, and acute pain. In addition to computer searches, the ancestry approach was utilized, in which the reviewer extrapolates information by reviewing reference lists of related research studies for topic relevance [25]. Every attempt was made to include all studies that meet the inclusion criteria. After retrieval of all studies, they were reviewed on two separate oc- 
casions, by two separate reviewers, to ensure adequate sampling. Fourteen studies met inclusion criteria.

To ensure rigor, reliability was tested by two reviewers. "Through this process potential biases are countered, broad experience can be brought to the task, and the reliability of the recorded evidence enhanced” [31]. Cooper (1998) suggests that both primary researches examine data looking for extreme values, errors in recording, or other indicators of unreliable measurements [27].

Stetler and collegues (1998) describe six different levels of research. Level I refers to evidence obtained from a meta-analysis of multiple controlled studies. It is the strongest type of research. Level II illustrates an individual experimental study. Level III indicates a quasi-experimental study, such as nonrandomized controlled single group pre-post test, time series, or matched case-controlled studies. Level IV describes non-experimental study, such as correlational descriptive research and qualitative or case studies. Level V indicates a case report, program evaluation, or quality improvement data. Lastly, Level VI describes the opinions of expert committees or respected authorities based on their clinical experience. Additionally, "quality from any level can range from A to D and reflects basic scientific credibility of the overall study/project. An A reflects a very well-designed study/project. If quality is rated as a D, (i.e., the study/project has a major flaw that raises serious questions about the believability of the findings), it is automatically eliminated from consideration” [31]. These levels will be presented later in the results section.

\subsection{Results}

A research synthesis table is presented in Table 1 . Table 1 is a summary of the reviewed articles with purpose, setting, sample, design, and study results. Six of the fourteen (43\%) studies employed descriptive designs [19] [29] [32]-[35]. Additionally, six studies (43\%) applied retrospective cohort study designs [15] [36]-[40]. Minick

\section{Table 1. Reviewed studies.}

\begin{tabular}{|c|c|c|c|c|c|}
\hline Author/Year & Purpose & Setting & Sample & $\begin{array}{l}\text { Design and Level of } \\
\text { Evidence }\end{array}$ & Results \\
\hline $\begin{array}{c}\text { Fuentes, E., } \\
\text { Kohn, M., } \\
\text { Neighbor, M. (2002) }\end{array}$ & $\begin{array}{c}\text { To determine } \\
\text { whether non-white } \\
\text { patients with } \\
\text { long-bone fractures } \\
\text { were less likely to } \\
\text { receive analgesics } \\
\text { than White patients } \\
\text { with similar injuries }\end{array}$ & $\begin{array}{l}\text { Urban emergency } \\
\text { department }\end{array}$ & $\begin{array}{c}\mathrm{N}=494 \\
\text { Adults aged } 18 \text { - } 55 \text { with } \\
\text { isolated long bone } \\
\text { fractures. } \\
\text { Compared } \\
\text { African-American, } \\
\text { Hispanic, and White } \\
\text { patients }\end{array}$ & $\begin{array}{l}\text { Retrospective cohort } \\
\text { III }\end{array}$ & $\begin{array}{l}\text { No difference in the } \\
\text { administration of } \\
\text { analgesics to white and } \\
\text { non-white patients with } \\
\text { long bone fractures. }\end{array}$ \\
\hline $\begin{array}{c}\text { Pletcher, M., } \\
\text { Kertesz, S., } \\
\text { Kohn, M., \& } \\
\text { Gonzales, R. (2008) }\end{array}$ & $\begin{array}{l}\text { To determine } \\
\text { whether opioid } \\
\text { prescribing in } \\
\text { emergency } \\
\text { departments has } \\
\text { increased; whether } \\
\text { non-Hispanic White } \\
\text { patients are more } \\
\text { likely to receive an } \\
\text { opioid than other } \\
\text { racial/ethnic groups; } \\
\text { and whether } \\
\text { differential } \\
\text { prescribing by } \\
\text { race/ethnicity has } \\
\text { diminished since } \\
2000\end{array}$ & $\begin{array}{l}\text { Various United } \\
\text { States (US) } \\
\text { emergency } \\
\text { departments }\end{array}$ & $\begin{array}{c}\mathrm{N}=156,729 \\
\text { Utilized NHAMCS to } \\
\text { identify US emergency } \\
\text { department visits } \\
\text { 1993-2005 with } \\
\text { diagnosis of pain } \\
\text { Compared White, Black, } \\
\text { Hispanic, and } \\
\text { Asian/other }\end{array}$ & $\begin{array}{l}\text { Descriptive } \\
\text { IV }\end{array}$ & $\begin{array}{l}\text { Opioid prescribing } \\
\text { increased in the } \\
\text { emergency department } \\
\text { after national quality } \\
\text { improvement initiatives, } \\
\text { but differences in opioid } \\
\text { prescribing by } \\
\text { race/ethnicity have not } \\
\text { diminished. }\end{array}$ \\
\hline $\begin{array}{c}\text { Mills, A. } \\
\text { Shofer, F., } \\
\text { Boulis, A., } \\
\text { Holena, D., \& } \\
\text { Abbuhl, S. (2011) }\end{array}$ & $\begin{array}{c}\text { To assess whether } \\
\text { patient race affects } \\
\text { analgesia } \\
\text { administration for } \\
\text { patients presenting } \\
\text { with back or } \\
\text { abdominal pain. }\end{array}$ & $\begin{array}{l}2 \text { Urban emergency } \\
\text { departments }\end{array}$ & $\begin{array}{l}\mathrm{N}=20,125 \\
\text { Adults presenting with } \\
\text { back or abdominal pain } \\
\text { for a } 4 \text { year period. } \\
\text { Compared non-Whites } \\
\text { and Whites }\end{array}$ & $\begin{array}{l}\text { Retrospective cohort } \\
\text { III }\end{array}$ & $\begin{array}{l}\text { Nonwhite patients } \\
\text { presenting to the } \\
\text { emergency department for } \\
\text { abdominal or back pain } \\
\text { were less likely than } \\
\text { whites to receive analge- } \\
\text { sia and waited longer for } \\
\text { their opiate medication. }\end{array}$ \\
\hline
\end{tabular}


Continued

\begin{tabular}{|c|c|c|c|c|c|}
\hline Author/year & Purpose & Setting & Sample & $\begin{array}{c}\text { Design and Level of } \\
\text { Evidence }\end{array}$ & Results \\
\hline $\begin{array}{c}\text { Bijur, P., } \\
\text { Berard, A., } \\
\text { Nestor, J., } \\
\text { Calderon, Y., } \\
\text { Davitt, M., \& } \\
\text { Gallagher, J. (2008) }\end{array}$ & $\begin{array}{l}\text { To assess whether } \\
\text { there are racial or } \\
\text { ethnic disparities in } \\
\text { receipt of analgesics } \\
\text { for pain from } \\
\text { long-bone fracture } \\
\text { more recently and in } \\
\text { a different region of } \\
\text { the US }\end{array}$ & $\begin{array}{c}\text { Emergency } \\
\text { department in } \\
\text { municipal hospital }\end{array}$ & $\begin{array}{c}\mathrm{N}=449 \\
\text { aged } 15 \text { - } 55 \text { years with } \\
\text { isolated long bone } \\
\text { fracture within past } 24 \\
\text { hours } \\
\text { Whites, African Ameri- } \\
\text { cans, and } \\
\text { Hispanics }\end{array}$ & $\begin{array}{l}\text { Retrospective chart } \\
\text { review } \\
\text { III }\end{array}$ & $\begin{array}{l}\text { No evidence of racial or } \\
\text { ethnic disparities in the } \\
\text { management of pain from } \\
\text { long-bone fractures. }\end{array}$ \\
\hline $\begin{array}{l}\text { Tamayo-Sarver, } \\
\text { Hinze, Cydulka, \& } \\
\text { Baker (2003) }\end{array}$ & $\begin{array}{l}\text { Examined racial and } \\
\text { ethnic disparities in } \\
\text { analgesic prescription } \\
\text { among a national } \\
\text { sample of emergency } \\
\text { department patients }\end{array}$ & $\begin{array}{l}\text { Non-federal, } \\
\text { short-stay hospital } \\
\text { emergency } \\
\text { departments }\end{array}$ & $\begin{array}{c}\mathrm{N}=67,487 \\
\text { Utilized 1997, 1998, and } \\
1999 \text { National Hospital } \\
\text { Ambulatory Medical } \\
\text { Care Survey } \\
\text { Compared Blacks, } \\
\text { Whites, and Latinos }\end{array}$ & $\begin{array}{l}\text { Descriptive } \\
\text { IV }\end{array}$ & $\begin{array}{l}\text { No difference in overall } \\
\text { analgesic prescription. } \\
\text { Blacks and Latinos in the } \\
\text { entire sample were less } \\
\text { likely than Whites to } \\
\text { receive an opioid } \\
\text { analgesia. }\end{array}$ \\
\hline $\begin{array}{l}\text { Heins, Heins, } \\
\text { Grammas, } \\
\text { Costello, Huang, \& } \\
\text { Mishra (2006) }\end{array}$ & $\begin{array}{l}\text { Examined the } \\
\text { influence of patient } \\
\text { and provider } \\
\text { characteristics of } \\
\text { emergency } \\
\text { department and } \\
\text { discharge analgesia } \\
\text { and opioid } \\
\text { prescribing practices }\end{array}$ & $\begin{array}{l}\text { Urban emergency } \\
\text { department }\end{array}$ & $\begin{array}{c}\mathrm{N}=868 \\
\text { patients with } \\
\text { musculoskeletal pain and } \\
10 \text { core attending } \\
\text { physicians over an } 8 \\
\text { week period in } 2004 \\
\text { Compared Black, Whites, } \\
\text { and Other }\end{array}$ & $\begin{array}{l}\text { Retrospective, } \\
\text { descriptive } \\
\text { IV }\end{array}$ & $\begin{array}{l}\text { White patients were } 1.8 \\
\text { times more likely to } \\
\text { receive opioids in the } \\
\text { emergency department } \\
\text { and } 81 \% \text { more likely to } \\
\text { receive a discharge pre- } \\
\text { scription than were } \\
\text { blacks. Providers with > } \\
3 \text { years' experience were } \\
40 \% \text { less likely to } \\
\text { prescribe ED analgesia } \\
\text { compared with those with } \\
<3 \text { years' of experience. }\end{array}$ \\
\hline
\end{tabular}

\begin{tabular}{|cc}
\hline Author/year & Purpose \\
\hline & \\
& To describe \\
& parenteral analgesic \\
Hostetler, & and sedative (PAS) \\
Auinger, \& & use among patients \\
treated in the US \\
Szilagyi (2002) & emergency \\
& departments \\
&
\end{tabular}

Setting

To determine if current emergency

Quazi,

Eberhart,

Jacoby, \&

Heller (2008) department practice has been altered subsequent to the widespread recognition of ethnic inequalities in this setting

\section{Sample}

US emergency
departments

$$
\mathrm{N}=157932
$$

Utilized NHAMCS data representing 1992-1997. Examined in 3 different groups: the entire population, orthopedic injuries (fractures), and wound-related injuries (lacerations).

Compared African

American and Whites

US emergency departments

$$
\mathrm{N}=7504
$$

Utilized NHAMCS to analyze analgesic treatment with respect to race for complaints of headache and long bone fractures comparing 1995-1999 to 2000-2003. Compared Black, Whites, and Hispanics

Children, African

Descriptive IV

$\begin{array}{cc} & \text { Blacks and Hispanics } \\ & \text { remain less likely to } \\ \text { receive opioid analgesics } \\ \text { than their white counter- } \\ \text { Descriptive } & \text { parts for complaints of } \\ \text { IV } & \text { headache. All ethnic } \\ & \text { groups with long bone } \\ \text { fractures were treated } \\ \text { similarly }\end{array}$
American patients, and those covered by Medicaid insurance were least likely to receive PAS. 


\begin{tabular}{|c|c|c|c|c|c|}
\hline $\begin{array}{l}\text { Epps, Ware \& } \\
\text { Packard (2008) }\end{array}$ & $\begin{array}{l}\text { To determine } \\
\text { whether wait time } \\
\text { differences in pain } \\
\text { treatment existed for } \\
\text { ethnic and minority } \\
\text { adults who were } \\
\text { admitted to the ED } \\
\text { suffering from long } \\
\text { bone fractures. }\end{array}$ & $\begin{array}{l}\text { Two Georgia } \\
\text { emergency } \\
\text { department's }\end{array}$ & $\begin{array}{c}\mathrm{N}=234 \\
\text { Compared } \\
\text { European-American, } \\
\text { African-Americans, \& } \\
\text { Hispanics }\end{array}$ & $\begin{array}{l}\text { Quantitative, } \\
\text { retrospective } \\
\text { III }\end{array}$ & $\begin{array}{l}\text { Significant wait time was } \\
\text { found between Hispanic } \\
\text { and European-American } \\
\text { patients. Hispanic patients } \\
\text { waited an average of } 102 \\
\text { mins. for the first dose of } \\
\text { analgesia, compared to } \\
\text { the average wait time of } \\
67 \text { mins. for } \\
\text { European-Americans. }\end{array}$ \\
\hline Author/year & Purpose & Setting & Sample & $\begin{array}{c}\text { Design and Level of } \\
\text { Evidence }\end{array}$ & Results \\
\hline $\begin{array}{c}\text { Ware, Epps, } \\
\text { Clark \& } \\
\text { Chatterjee (2012) }\end{array}$ & $\begin{array}{l}\text { To investigate pain } \\
\text { assessment and } \\
\text { treatment for adults } \\
\text { admitted to the } \\
\text { emergency } \\
\text { department suffering } \\
\text { from long-bone } \\
\text { fractures. }\end{array}$ & $\begin{array}{l}\text { Midsouth Regional } \\
\text { Medical Center }\end{array}$ & $\begin{array}{c}\mathrm{N}=200 \\
\geq 18 \text { years old; admitted } \\
\text { to ED suffering from } \\
\text { long-bone fractures. } \\
\text { Compared African } \\
\text { Americans, Caucasians, } \\
\text { one Asian American, } \\
\text { three Hispanic } \\
\text { Americans, one patient } \\
\text { classified as "other". }\end{array}$ & $\begin{array}{l}\text { Retrospective chart } \\
\text { review } \\
\text { III }\end{array}$ & $\begin{array}{l}\text { Ethnicity did not } \\
\text { influence pain } \\
\text { management. }\end{array}$ \\
\hline $\begin{array}{c}\text { Minick, Clark, } \\
\text { Dalton, Horne, } \\
\text { Greene \& Brown. } \\
\text { (2012) }\end{array}$ & $\begin{array}{l}\text { To investigate the } \\
\text { adequacy of pain } \\
\text { management for } \\
\text { patients with } \\
\text { long-bone fractures } \\
\text { seen in the emergen- } \\
\text { cy department and to } \\
\text { determine whether } \\
\text { racial disparities exist }\end{array}$ & $\begin{array}{l}\text { Urban emergency } \\
\text { departments in } \\
\text { Southeastern US }\end{array}$ & $\begin{array}{c}\mathrm{N}=218 \\
\text { Patients with long -bone } \\
\text { fractures } \\
\text { Compared Blacks and } \\
\text { Whites }\end{array}$ & $\begin{array}{l}\text { Exploratory, } \\
\text { correlational } \\
\text { III }\end{array}$ & $\begin{array}{l}\text { Younger patients, Blacks, } \\
\text { and those with higher } \\
\text { pain severity were more } \\
\text { likely to receive } \\
\text { inadequate pain } \\
\text { management than white } \\
\text { patients. }\end{array}$ \\
\hline $\begin{array}{l}\text { Tsai, Sullivan, } \\
\text { Gordon, Kaushal, } \\
\text { Magid, Blumenthal \& } \\
\text { Camargo. (2012) }\end{array}$ & $\begin{array}{l}\text { To investigate } \\
\text { racial/ethnic } \\
\text { differences in } \\
\text { emergency care for } \\
\text { patients with joint } \\
\text { dislocation. }\end{array}$ & $\begin{array}{l}53 \text { US urban ED’s } \\
\text { across } 19 \text { states }\end{array}$ & $\begin{array}{c}\mathrm{N}=1945 \\
\text { Patients with principle } \\
\text { diagnosis of joint } \\
\text { dislocation between } \\
\text { 2003-2005 } \\
\text { Compared White, Black, } \\
\text { and Hispanic }\end{array}$ & $\begin{array}{l}\text { Descriptive } \\
\text { IV }\end{array}$ & $\begin{array}{c}\text { Black patients were less } \\
\text { likely to receive any } \\
\text { analgesic treatment or } \\
\text { opioid treatment, waited } \\
\text { longer to receive } \\
\text { analgesia, and less likely } \\
\text { to receive reassessments } \\
\text { of pain compared to white } \\
\text { patients. }\end{array}$ \\
\hline $\begin{array}{c}\text { Yen, Kim, } \\
\text { Stremski, \& } \\
\text { Gorelick (2003) }\end{array}$ & $\begin{array}{l}\text { To determine the } \\
\text { pattern of analgesic } \\
\text { use among children } \\
\text { of different race and } \\
\text { ethnicity presenting } \\
\text { with isolated long } \\
\text { bone fractures in } \\
\text { emergency } \\
\text { departments across } \\
\text { the US }\end{array}$ & US EDs & $\begin{array}{l}\mathrm{N}=1030 \\
\text { Utilized NHAMCS data } \\
\text { for } 7 \text { years (1992-1998). } \\
\text { Compared non-Hispanic } \\
\text { White, Black, and } \\
\text { Hispanic ethnicity }\end{array}$ & $\begin{array}{l}\text { Descriptive } \\
\text { IV }\end{array}$ & $\begin{array}{l}\text { Race and ethnicity did not } \\
\text { affect the likelihood of } \\
\text { receiving any analgesic } \\
\text { medication, including } \\
\text { opioids. }\end{array}$ \\
\hline Author/year & Purpose & Setting & Sample & $\begin{array}{c}\text { Design and Level of } \\
\text { Evidence }\end{array}$ & Results \\
\hline $\begin{array}{l}\text { Bijur, Berard, } \\
\text { Esses, Calderon, \& } \\
\text { Gallagher (2008) }\end{array}$ & $\begin{array}{l}\text { To test the hypothesis } \\
\text { that a smaller number } \\
\text { of Hispanic and } \\
\text { African American } \\
\text { patients receive } \\
\text { analgesics for the } \\
\text { pain of long-bone } \\
\text { fracture than do their } \\
\text { white counterparts }\end{array}$ & 2 Urban EDs & $\begin{array}{l}\mathrm{N}=345 \\
\text { age } 18 \text { - } 45 \text { years with } \\
\text { long bone fractures } \\
\text { Compared Hispanic, } \\
\text { African Americans, and } \\
\text { White patients }\end{array}$ & $\begin{array}{c}\text { Prospective } \\
\text { Observational } \\
\text { IV }\end{array}$ & $\begin{array}{l}\text { Administration of } \\
\text { analgesics was not } \\
\text { associated with race or } \\
\text { ethnicity }\end{array}$ \\
\hline
\end{tabular}


et al. (2012) utilized an exploratory, correlational design [41]. Lastly, Bijur et al. (2008) instituted a prospective, observational study design [38].

\subsection{Setting}

A Level I trauma designation was identified in four studies [15] [36] [38] [42]. Four studies did not disclose an ED trauma designation [37] [39]-[41]. Level I trauma centers are equipped to provide comprehensive medical service to traumatically injured patients. Trauma centers may be designated as Levels I-V with I being the highest level and having the most resources to care for complex injures [43].

Five studies (36\%) utilized the National Hospital Ambulatory Medical Care Survey (NHAMCS) as a nationally representative sample of ED visits within the United States [19] [29] [32]-[34]. The NHAMCS is designed to collect data on the utilization and provision of ambulatory care services in hospital emergency and outpatient departments. Findings are based on a national sample of visits to the emergency departments and outpatient departments of non-institutional general and short-stay hospitals [44].

Lastly, one study by Tsai et al. (2012) utilized the National Emergency Department Safety Study's (NEDSS) joint dislocation component to collect data. The NEDSS is a multi-center study aimed at characterizing system and clinician factors associated with error occurrence in the ED [35]. The NEDSS focuses on acute myocardial infarctions, acute asthma, and joint dislocation. It is coordinated by the Emergency Medicine Network [45].

\subsection{Duration of Studies}

Significant variability existed between the duration of the studies analyzed. The range of duration was 4 weeks to 13 years, utilizing ED visits from 1992 through 2007. The shortest study period was conducted in 4 week intervals for three consecutive years [19]. Heins et al. (2006) organized an eight week study period in 2004 [15]. Minick et al. (2012) conducted a study over 3.5 months, and Fuentes et al. (2002) conducted a study for eleven months [36] [41]. Six studies spanned two to four years duration [35] [37]-[39] [42], while Hostetler et al. (2002) and Yen et al. (2003) conducted studies over five and six year periods, respectively [32] [33]. The longest study surveyed ED visits over a thirteen year period from 1993-2005 [29]. Ware et al. (2012) studied a convenience sample of 200 ED patients but did not specify a particular study time period [40].

\subsection{Age of Subjects}

Six of the fourteen studies (43\%) studied adult and pediatric patients that presented to the ED [29] [33]-[35] [38] [41]. Yen, Kim, Stremski, \& Gorelick (2003) studied pediatric patients, exclusively [32]. Six studies (43\%) studied adults [15] [36]-[40]. Tamayo-Sarver et al. (2003) did not report the inclusion age of participants but reported a mean age of 54.78 years [19].

\subsection{Race and Ethnicity of Subjects}

Race and ethnicity was identified by self-report or by reports of the ED staff.

Eight of the fourteen studies (57\%) compared the pain management of African American, Caucasian, and Hispanic patients [19] [32] [34]-[36] [38] [39] [42]. No differences between African American, Hispanic, and Caucasian patients were noted in analgesic prescribing in five of the eight studies [32] [36] [38] [42] [46]. However, three of the eight studies identified disparities. It was found that Black and Hispanic patients were less likely to receive opioid analgesic treatment when compared to White patients [34] [35]; and waited longer for analgesia [35] [39].

Three of the fourteen (21\%) studies compared pain management practices between African American and Caucasian patients. Disparities were found in two of the three studies [33] [41]. They found that African American patients were less likely to receive analgesia (Hostetler et al., 2002) and least likely to receive adequate pain management [41]. The third study did not find a difference in pain management with regards to wait time to receive analgesia between African Americans and Caucasians [40].

The remaining three studies (29\%) found that when compared to Caucasian patients, African American and “other", non-White, ethnicities, were less likely to receive analgesia [15] [29] [37]. Pletcher et al. (2008) conducted a study to evaluate whether or not quality improvement initiatives regarding pain management has caused these disparities to diminish over time and found that although national quality improvement initiatives 
have been instituted, the prescribing differences between Caucasians and African Americans have not diminished [29].

\subsection{Type of Pain}

Seven of the fourteen studies (50\%) evaluated pain management among patients presenting to the ED exclusively with long bone fractures [32] [36] [38]-[42]. There was no difference among analgesic prescribing for patients with long bone pain in five of the seven studies [32] [36] [38] [40] [42]. However, Blacks with long bone fractures were found to wait longer for analgesia and receive inadequate analgesia in two of the studies [39] [41].

In addition to long bone fractures, the pain management of headaches [19] [29] [34] nephrolithiasis [29], lacerations [33], back pain [15] [19] [29] [37], joint dislocation [35], and abdominal pain [29] [37] were evaluated. Similar pain management disparities were noted among the ethnic minorities with these types of pain. Patients suffering from headaches received some form of analgesia in the three studies that evaluated analgesic prescribing for this symptom; however, Whites were more likely to receive opioid analgesic for this complaint [29] [34] [46]. Pletcher et al., 2008 found that although nephrolithiasis is a diagnosable pain, opioid prescribing by race/ethnicity remained statistically significant with non-Whites receiving less opioid analgesia than Whites for this complaint [29]. Joint dislocation, also being a verifiable painful condition, presented disparities in a study conducted by Tsai et al., 2012 [35]. Black patients presenting to the ED with joint dislocation were less likely to receive any analgesia and waited approximately 30 minutes longer to receive the treatment that was prescribed. Back and abdominal pain, being subjective complaints, also added to disparities in opioid prescribing. NonWhite patients were less likely to receive any analgesia, received less opioid analgesia, and waited longer for opioid analgesia when presenting to the ED with these complaints [15] [29] [37] [46].

\subsection{Type of Analgesia}

Three of the fourteen studies (21\%) compared ethnic groups that did not receive analgesia to groups that were prescribed any type of analgesia in the ED [35] [38] [41]. Bijur et al. (2008) found no difference in analgesia prescribing among ethnic groups [38]. However, studies completed by Tsai (2012) and Minick (2012) found that Blacks were more likely to receive inadequate analgesia [35] [41].

Nine studies (64\%) compared the prescription of opioid analgesics to non-opioid analgesics among different ethnicities [15] [29] [32] [34] [37]-[40] [46]. Blacks were noted to be prescribed opioids at lower rates, waited longer to receive opioid analgesia, [15] [29] [37] [39] [46] and were prescribed non-opioid analgesia [34] more than any other race/ethnicity. Contrarily, no differences in opioid analgesic prescribing practices were noted in three of the nine comparative studies [32] [38] [40].

Two studies (14\%) compared the administration of parental analgesia among different ethnic groups. Hostetler et al. (2002) found that African Americans were least likely to receive parental analgesia and sedation in the ED [33]. Conversely, Fuentes et al. (2002) found that race was not a factor in the administration of parental analgesia [36].

\subsection{Contributors to Pain Management Disparities}

Eight of the fourteen studies (57\%) offer potential contributors to pain management disparities in the ED. Discrepancies in communication as a possible cause of pain management disparities was cited in five studies [29] [33] [34] [39] [46]. The possibility of a patient's communication being interpreted as an exaggeration of pain, especially those with subjective complaints, was cited as lending to racial bias and pain management disparities [29] [34] [37]. Pletcher et al. (2008) proposed that White patients may be more assertive, have higher expectations of pain relief, and more likely to request stronger pain meds [29]. The study by Epps et al. (2008) proposed that a language barrier between Spanish speaking patients and English speaking providers may have contributed to pain management disparities [39]. An alternative hypothesis contributing to pain management disparities is that female patients are better at communicating their pain [33].

Provider characteristics were noted to contribute to pain management disparities in studies conducted by Heins et al. (2006) and Minick et al. (2012) [15] [41]. Emergency Medicine (EM) trained providers with fewer than 3 years' experience were significantly more likely to prescribe analgesia than non-EM trained and more 
experienced attending physicians [15]. Additionally, Minick et al. (2012) cite that providers do not always follow expert recommendation regarding use of the most appropriate measure of pain, as a primary part of their decisions about pain management [41]. Finally, Tamayo-Sarver et al. (2003) and Heins et al. (2006) stated that trust may be an issue contributing to a physician's reluctance to prescribe opioids if a patient lacked regular source of care or if the provider felt a patient was being dishonest regarding complaints of pain [15] [46].

\section{Discussion}

From the data extracted from the fourteen reviewed articles meeting the criteria for inclusion, it is apparent that racial and ethnic disparities in pain management continue to exist in the ED setting. These disparities are most prevalent among minorities experiencing pain that cannot be verified or quantified via diagnostic studies, such as headache, back pain, and abdominal pain. It is clear that pain management is a multifactorial problem requiring a congruous approach. The Joint Commission developed pain management standards on January 1, 2001. These standards specified the patient's right to appropriate assessment and management of pain and ongoing, periodic reassessments of pain. Most of the studies included the pain management of long bone fractures as a sole measure, or as it compared to other types of pain. Seminal research into pain management disparities by Todd and colleagues studied the effect of ethnicity on the administration of pain medication in patients with long-bone extremity fractures, finding that Hispanic and African American patients failed to receive adequate pain management when compared to White patients [14] [47]. These studies sparked a fire storm of research to determine the generalizability of these findings.

This integrative review of available current literature points to no specific cause of the disparities but suggests that ineffective communication [29] [39] [46]; physician perception of the patient and the experience of pain [29] [34] [37] [39]; racial/ethnic bias [37]; and provider characteristics such as experience, education, and reluctance to follow expert recommendation [15] [41] as contributors to pain management disparities in the ED. While a number of the studies reviewed proved to be beneficial in identifying disparities and possible causes, all of them had limitations. The most striking limitations were NHAMCS use, retrospective study designs, and demographics. Multiple studies noted that the NHAMCS offered limited clinical details about each patient encounter. The survey does not disclose specific encounter details such as whether the patient requested pain medication, what quantity of opioids were prescribed or any confounding factors, such as substance abuse [29] [32] [33] [46]. Limitations of the retrospective study design were cited as the potential for missing data, lack of ability to verify data accuracy, and lack of encounter details such as requests for pain medication and non-verbal cues of pain [37]-[41]. Some studies cited demographics, such as an urban setting serving mostly African American and Hispanic patients as limitations [37] [38] [42]. These settings potentially limit the generalizability of the findings.

The ultimate goal of this integrative review is to use the information gathered to draw attention to the need for more consistent methods of treating pain in the ED. It is evident from the studies examined in this review that ethnicity has an impact on analgesic prescribing practices in the ED. EDs are an important part of the underserved community that provide care when no other health care services are available or symptoms are too severe to be addressed in primary care. In addition to the underserved community, EDs afford care to entire communities when the services of primary care provider are unavailable or inappropriate. Our task in the near future is to develop pain management guidelines for all types of pain presenting to the ED. It is evident from this review that disparities in pain management are a continuing epidemic. This study includes studies from the US; however, the US is a home of multiple ethnicities. The task of creating guidelines is not easy because the cultural diversity in the US requires providers to obtain additional education in cultural competence to meet the needs of each community. Eventually, nationwide guidelines offering fair and equitable pain management should be implemented in all EDs. These guidelines should be initiated as soon as possible in accordance with Joint Commission pain management standards. This endeavor may pose several challenges. First, each patient encounter is unique and universal guidelines will not apply to all situations. Secondly, providers will have to exude confidence in pain management strategies and the willingness to adhere to guidelines. Thirdly, the incorporation of guidelines does not eliminate racial/ethnic biases which are difficult to evaluate and document. It is our belief that for guidelines to be adhered to, components must include age, type and severity of pain, medical history, and substance abuse history. The severity of pain component should be culturally relevant given the various expressions of pain among ethnicities. 


\subsection{Nursing Implications}

There is sufficient evidence that racial and ethnic disparities in analgesic prescribing continue to exist. Pain, being a subjective complaint, is valued by its interpretation. A cause of oligoanalgesia in the ED has been linked to ineffective communication between the patient and provider and could be predicted by the patient and physician's perception of their interaction, and the physician's perception of whether or not a patient is exaggerating symptoms [17] [19]. Through interpretation of the interaction, the physician has the daunting task of deciding if the patient is experiencing pain, if it is sufficient enough to be treated, and if so, with which type of analgesia. "It is possible that misinterpreted information from the patient's description of history that does not correspond to the objective information that a physician has obtained may lead to the misperception that a patient is exaggerating symptoms to obtain pain medications" [17]. Contrarily, providers were more likely to treat a complaint of pain that could be verified, as noted in studies involving long bone fracture.

The role of the nurse is to achieve equitable pain management across all racial/ethnic groups. A careful and fair assessment of pain complaints should be conducted to provide the best opportunity for achieving satisfactory relief. Ethnic differences in expression and reporting of symptoms must be considered given the overrepresentation of ethnic minorities in the ED. Changing medical practice is complex. However, new strategies are necessary to reduce disparities in this arena. Providers must realize that all patients may not possess the skills to eloquently express their complaints of pain and increasing cultural competence is a priority. As emergency room providers, nurses "must be prepared to render effective, respectful, and compassionate care to every individual who presents to the ED. It is our duty to overcome whatever obstacles threaten to prevent our delivering such care, whether the obstacles are based in racial differences or personal idiosyncrasies" [48]. Doing so will enhance the patient-provider relationship and ensure that providers have a better understanding of the specific health needs of minority communities.

\subsection{Study Limitations}

The studies reviewed were limited by their design and setting, and sample. No random controlled trials or metaanalysis were identified in the search. All of the studies utilized chart reviews or surveys which could not be verified for accuracy or account for confounding factors such as a patients request for, or refusal of, pain medication.

\section{Conclusion}

Disparities in pain management is evident in the ED, which is often considered a safety net of health care, sometimes functioning as the sole provider for the uninsured, underinsured, and those that lack access to primary care. As a result, the ED provides care for a disproportionate number of minority patients. Given this situation, it would be detrimental if we overlooked the areas with these disparities and failed to investigate the best strategies to reduce them. Research must extend beyond observational to interventional. Also, cultural competence and racial bias must be considered when discussing discourse in pain management.

\section{References}

[1] Merriam-Webster Online Medical Dictionary (2013) Pain. www.merriam-webster.com/medical/pain

[2] Dubois, M., Gallagher, R. and Lippe, P. (2009) Pain Medicine Position Paper. Pain Medicine, 10, 972-1000. http://dx.doi.org/10.1111/j.1526-4637.2009.00696.x

[3] Gindi, R., Cohen, R. and Kirzinger, W. (2012) Emergency Room Use among Adults Aged 18-64: Early Release of Estimates from the National Health Interview Survey, January-June 2011. National Center for Health Statistics. May 2012. http://www.cdc.gov/nchs/nhis/releases.htm.

[4] National Ambulatory Medical Care Survey (2009) National Ambulatory Medical Care Survey: 2009 Emergency Department Summary Tables. http://www.cdc.gov/nchs/data/ahcd/nhamcs emergency/2009 ed web tables.pdf

[5] Centers for Medicare and Medicaid Services (2012) Emergency Medical Treatment and Labor Act (EMTALA). http://www.cms.gov/Regulations-and-Guidance/Legislation/EMTALA/index.html

[6] Hadley, J. and Cunningham, P. (2004) Availability of Safety Net Providers and Access to Care of Uninsured Persons. Health Services Research, 39, 1527-1546. http://dx.doi.org/10.1111/j.1475-6773.2004.00302.x 
[7] May, J., Cunningham, P. and Hadley, J. (2004) Most Uninsured People Unaware of Health Care Safety Net Providers. Issue Brief Center for the Studying Health System Change, 90, 1-4. http://www.hschange.com/CONTENT/718/

[8] Cohen, R. and Martinez, M. (2012) Health Insurance Coverage: Early Release of Estimates from the National Health Interview Survey, 2011. National Center for Health Statistics. http://www.cdc.gov/nchs/data/nhis/earlyrelease/insur201206.pdf

[9] Centers for Disease Control (2011) Fact Sheet—CDC Health Disparities and Inequalities Report—US 2011. http://www.cdc.gov/minorityhealth/reports/CHDIR11/FactSheet.pdf

[10] Joint Commission on the Accreditation of Health Organizations (2012) Facts about Pain Management. http://www.jointcommission.org/pain_management/

[11] Mossey, J. (2011) Defining Racial and Ethnic Disparities in Pain Management. Clinical Orthopaedics and Related Research, 469, 1859-1870. http://dx.doi.org/10.1007/s11999-011-1770-9

[12] Green, C., Anderson, K.O., Baker, T.A., Campbell, L.C., Decker, S., Fillingim, R.B., et al. (2003) The Unequal Burden of Pain: Confronting Racial and Ethnic Disparities in Pain. Pain Medicine, 4, 277-294. http://dx.doi.org/10.1046/j.1526-4637.2003.03034.x

[13] Anderson, K., Mendoza, T.R., Valero, V., Richman, S.P., Russell, C., Hurley, J., et al. (2000) Minority Cancer Patients and Their Providers. Pain Management Attitudes and Practice. Cancer, 88, 1929-1938. http://dx.doi.org/10.1002/(SICI)1097-0142(20000415)88:8<1929::AID-CNCR23>3.0.CO;2-2

[14] Todd, K., Deaton, C., D’Adamo, A. and Goe, L. (2000) Ethnicity and Analgesic Practice. Annals of Emergency Medicine, 35, 11-16. http://dx.doi.org/10.1016/S0196-0644(00)70099-0

[15] Heins, J., Heins, A., Grammas, M., Costello, M., Huange, K. and Mishra, S. (2006) Disparities in Analgesia and Opioid Prescribing Practices for Patients with Musculoskeletal Pain in the Emergency Department. Journal of Emergency Nursing, 32, 219-224. http://dx.doi.org/10.1016/j.jen.2006.01.010

[16] Anderson, K., Green, C. and Payne, R. (2009) Racial and Ethnic Disparities in Pain: Causes and Consequences of Unequal Care. The Journal of Pain, 10, 1187-1204. http://dx.doi.org/10.1016/j.jpain.2009.10.002

[17] Miner, J., Biros, M., Trainor, A., Hubbard, D. and Beltram, M. (2006) Patient and Physician Perceptions as Risk Factors for Oligoanalgesia: A Prospective Observational Study of the Relief of Pain in the Emergency Department. Academic Emergency Medicine, 13, 140-146. http://dx.doi.org/10.1111/j.1553-2712.2006.tb01662.x

[18] Staton, L.J., Panda, M., Chen, I., Genao, I., Kurz, J., Pasanen, M., Mechaber, A.J., Menon, M., O’Rorke, J., Wood, J., Rosenberg, E., Faeslis, C., Carey, T., Calleson, D. and Cykert, S. (2007) When Race Matters: Disagreement in Pain Perception between Patients and Their Physicians in Primary Care. Journal of the National Medical Association, 99, 532-538.

[19] Tamayo-Sarver, J., Dawson, N., Hinze, S., Cydulka, R., Wigton, R., Albert, J., Ibrahim, S. and Baker, D. (2003) The Effect of Race/Ethnicity and Desirable Social Characteristics on Physicans’ Decisions to Prescribe Opioid Analgesics. Academic Emergency Medicine, 10, 1239-1248. http://dx.doi.org/10.1111/j.1553-2712.2003.tb00608.x

[20] Kposowa, A. and Tsunokai, G. (2002) Searching for Relief: Racial Differences in Treatment of Patients with Back Pain. Race \& Society, 5, 193-223. http://dx.doi.org/10.1016/j.racsoc.2004.01.004

[21] Siddall, P. and Cousins, M. (2004) Persistent Pain as a Disease Entity: Implications for Clinical Management. Anesthesia and Analgesia, 99, 510-520. http://dx.doi.org/10.1213/01.ANE.0000133383.17666.3A

[22] European Federation of International Association for the Study of Pain (2001) Declaration on Chronic Pain as a Major Healthcare Problem, a Disease in Its Own Right. http://efic.org/index.asp?sub=724B97A2EjBu1C

[23] Riley, J. and King, C. (2009) Self-Report of Alcohol Use for Pain in a Multi-Ethnic Community Sample. Journal of Pain, 10, 944-952. http://dx.doi.org/10.1016/j.jpain.2009.03.005

[24] Brennan, F., Carr, D. and Cousins, M. (2007) Pain Management: A Fundamental Human Right. Anesthesia and Analgesia, 105, 205-221. http://dx.doi.org/10.1213/01.ane.0000268145.52345.55

[25] Cooper, H. (1984) The Integrative Research Review: A Systematic Approach. Sage, Beverly Hills.

[26] Cooper, H. (1982) Scientific Guidelines for Conducting Integrative Research Reviews. Review of Educational Research, 52, 291-302. http://dx.doi.org/10.3102/00346543052002291

[27] Cooper, H. (1998) Synthesizing Research: A Guide for Literature Reviews. 3rd Edition, Sage, Thousand Oaks.

[28] Whittemore, R. and Knafl, K. (2005) The Integrative Review: Updated Methodology. Journal of Advanced Nursing, 52, 546-553. http://dx.doi.org/10.1111/j.1365-2648.2005.03621.x

[29] Pletcher, M., Kertesz, S., Kohn, M. and Gonzales, R. (2008) Trends in Opioid Prescribing by Race/Ethnicity for Patients Seeking Care in US Emergency Departments. Journal of American Medical Association, 299, 70-78.

http://dx.doi.org/10.1001/jama.2007.64 
[30] Platts-Mills, T., Esserman, D., Brown, L., Bortsov, A., Sloane, P. and McLean, S. (2012) Older US Emergency Department Patients Are Less Likely to Receive Pain Medication than Younger Patients: Results from a National Survey. Annals of Emergency Medicine, 60, 199-206. http://dx.doi.org/10.1016/j.annemergmed.2011.09.014

[31] Stetler, C., Morsi, D., Rucki, S., Broughton, S., Corrigan, B., Fitzgerald, J., Giuliano, K., Havener, P. and Sheridan, E. (1998) Utilization-Focused Integrative Reviews in a Nursing Service. Applied Nursing Research, 11, 195-206. http://dx.doi.org/10.1016/S0897-1897(98)80329-7

[32] Yen, K., Kim, M., Stremski, E. and Gorelick, M. (2003) Effect of Ethnicity and Race on the Use of Pain Medications in Children with Long Bone Fractures in the Emergency Department. Annals of Emergency Medicine, 42, 41-47. Http://Dx.Doi.Org/10.1067/Mem.2003.230

[33] Hostetler, M., Auinger, P. and Szilagyi, P. (2002) Parental Analgesic and Sedative Use among ED Patients in the United States: Combined Results from the National Hospital Ambulatory Medical Care Survey (NHAMCS) 1992-1997. American Journal of Emergency Medicine, 20, 83-87. http://dx.doi.org/10.1053/ajem.2002.31578

[34] Quazi, S., Eberhart, M., Jacoby, J. and Heller, M. (2007) Are Racial Disparities in ED Analgesia Improving? Evidence from a National Database. American Journal of Emergency Medicine, 26, 462-464. http://dx.doi.org/10.1016/j.ajem.2007.05.007

[35] Tsai, C., Sullivan, A., Gordon, J., Kaushal, R., Magid, D., Blumenthal, D. and Camargo, A. (2012) Racial/Ethnic Differences in Emergency Care for Joint Dislocation in 53 US EDs. The American Journal of Emergency Medicine, 30, 1970-1980. http://dx.doi.org/10.1016/j.ajem.2012.04.023

[36] Fuentes, E., Kohn, M. and Neighbor, M. (2002) Lack of Association between Patient Ethnicity or Race and Fracture Analgesia. Academic Emergency Medicine, 9, 910-915. http://dx.doi.org/10.1111/j.1553-2712.2002.tb02192.x

[37] Mills, A., Shofer, F., Boulis, A., Holena, D. and Abbuhl, S. (2011) Racial Disparity in Analgesic Treatment for ED Patients with Abdominal or Back Pain. American Journal of Emergency Medicine, 29, 752-756. http://dx.doi.org/10.1016/j.ajem.2010.02.023

[38] Bijur, P., Berard, A., Essess, D., Calderon, Y. and Gallagher, J. (2008) Race, Ethnicity, and Management of Pain from Long-Bone Fractures: A Prospective Study of Two Academic Urban Emergency Departments. Academic Emergency Medicine, 15, 589-597. http://dx.doi.org/10.1111/j.1553-2712.2008.00149.x

[39] Epps, C., Ware, L. and Packard, A. (2008) Ethnic Wait Time Differences in Analgesic Administration in the Emergency Department. Pain Management Nursing, 9, 26-32. http://dx.doi.org/10.1016/j.pmn.2007.07.005

[40] Ware, L., Epps, C., Clark, J. and Chatterjee, A. (2012) Do Ethnic Differences Still Exist in Pain Assessment and Treatment in the Emergency Department? Pain Management Nursing, 13, 194-201. http://dx.doi.org/10.1016/j.pmn.2010.06.001

[41] Minick, P., Clark, P., Dalton, J., Horne, E., Greene, D. and Brown, M. (2012) Long-Bone Fracture Pain Management in the Emergency Department. Journal of Emergency Nursing, 38, 211-217. http://dx.doi.org/10.1016/j.jen.2010.11.001

[42] Bijur, P., Berard, A., Nestor, J., Calderon, Y., Davitt, M. and Gallagher, E. (2007) No Racial or Ethnic Disparity in Treatment of Long-Bone Fractures. American Journal of Emergency Medicine, 26, 270-274. http://dx.doi.org/10.1016/j.ajem.2007.05.010

[43] American College of Surgeons (2007) Consultation Verification Program. http://www.facs.org/trauma/vcprogram.html

[44] Centers for Disease Control (2013) Ambulatory Health Care Data. http://www.cdc.gov/nchs/ahcd.htm

[45] Sullivan, A., Carmargo, C., Cleary, P., Gordon, J., Guadagnoli, E., Kaushal, R., Magid, D., Rao, S. and Blumenthal, D. (2007) The National Emergency Department Safety Study: Study Rationale and Design. Academic Emergency Medicine, 14, 1182-1189. http://dx.doi.org/10.1111/j.1553-2712.2007.tb02341.x

[46] Tamayo-Sarver, J., Hinze, S., Cydulka, R. and Baker, D. (2003) Racial and Ethnic Disparities in Emergency Department Analgesic Prescription. American Journal of Public Health, 93, 2067-2073. http://dx.doi.org/10.2105/AJPH.93.12.2067

[47] Todd, K., Samaroo, N. and Hoffman, J. (1993) Ethnicity as a Risk Factor for Inadequate Emergency Department Analgesia. Journal of the American Medical Association, 269, 1537-1539. http://dx.doi.org/10.1001/jama.1993.03500120075029

[48] Cone, D., Richardson, L., Todd, K., Betancourt, J. and Lowe, R. (2003) Health Care Disparities in Emergency Medicine. Academic Emergency Medicine, 10, 1176-1183. http://dx.doi.org/10.1111/j.1553-2712.2003.tb00600.x 
Scientific Research Publishing (SCIRP) is one of the largest Open Access journal publishers. It is currently publishing more than 200 open access, online, peer-reviewed journals covering a wide range of academic disciplines. SCIRP serves the worldwide academic communities and contributes to the progress and application of science with its publication.

Other selected journals from SCIRP are listed as below. Submit your manuscript to us via either submit@scirp.org or Online Submission Portal.
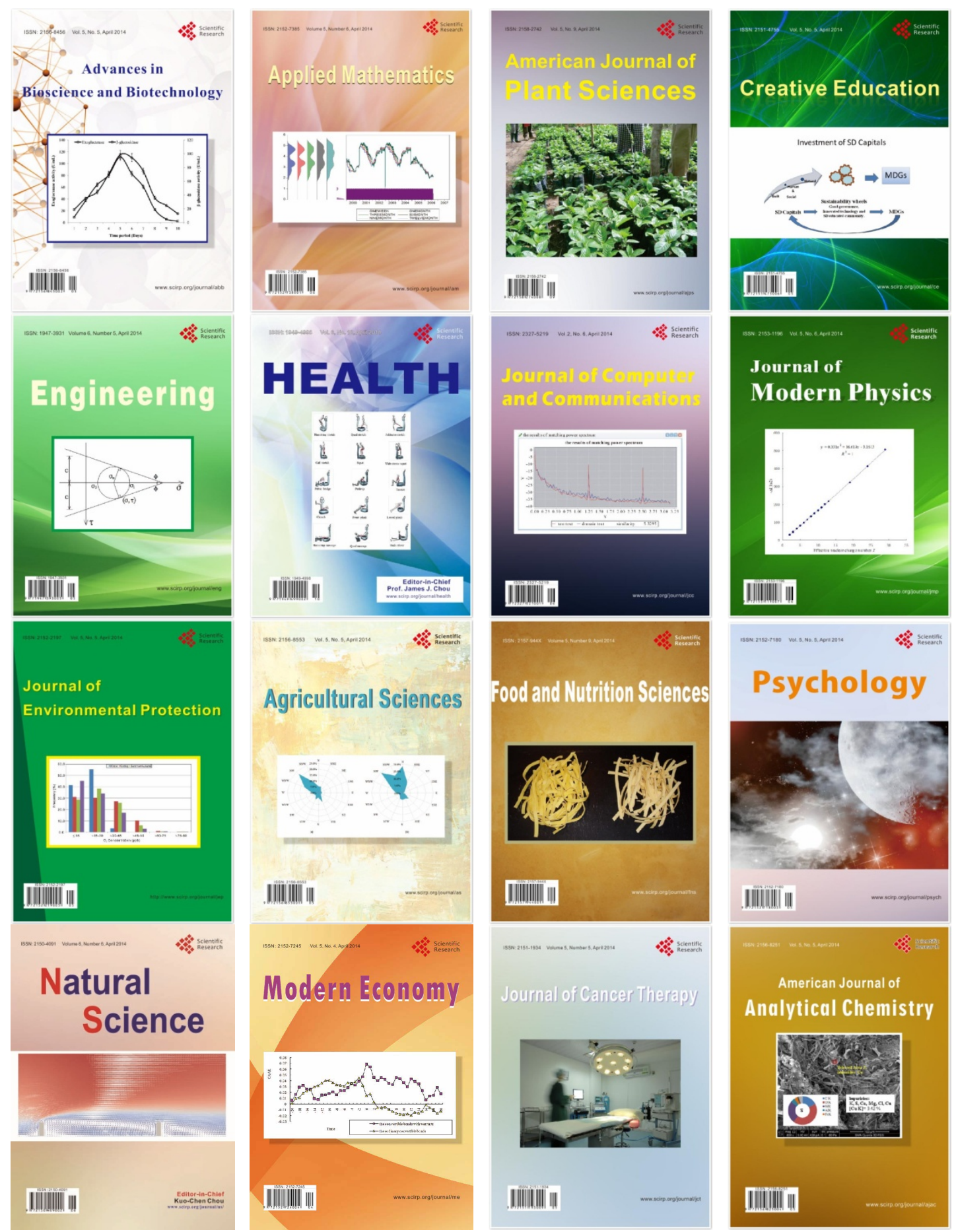